\title{
8
}
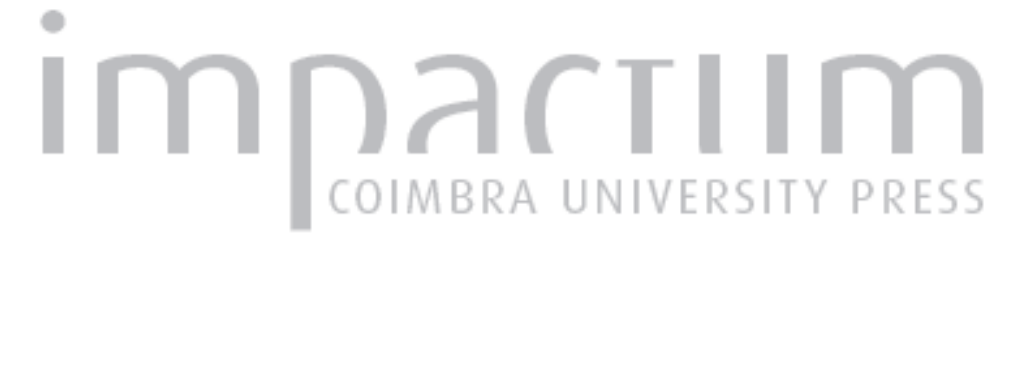

\section{Incêndios florestais no distrito da Guarda: fatores desencadeantes e consequências ambientais}

\author{
Autor(es): $\quad$ Henriques, Susete dos Anjos; Lourenço, Luciano
} Publicado por: $\begin{aligned} & \text { Faculdade de Letras da Universidade de Coimbra, Departamento de } \\ & \text { Geografia }\end{aligned}$

URL

persistente:

DOI: $\quad$ DOI:http://dx.doi.org/10.14195/0871-1623_32_12

\section{Accessed : $\quad$ 26-Apr-2023 10:37:31}

A navegação consulta e descarregamento dos títulos inseridos nas Bibliotecas Digitais UC Digitalis, UC Pombalina e UC Impactum, pressupõem a aceitação plena e sem reservas dos Termos e Condições de Uso destas Bibliotecas Digitais, disponíveis em https://digitalis.uc.pt/pt-pt/termos.

Conforme exposto nos referidos Termos e Condições de Uso, o descarregamento de títulos de acesso restrito requer uma licença válida de autorização devendo o utilizador aceder ao(s) documento(s) a partir de um endereço de IP da instituição detentora da supramencionada licença.

Ao utilizador é apenas permitido o descarregamento para uso pessoal, pelo que o emprego do(s) título(s) descarregado(s) para outro fim, designadamente comercial, carece de autorização do respetivo autor ou editor da obra.

Na medida em que todas as obras da UC Digitalis se encontram protegidas pelo Código do Direito de Autor e Direitos Conexos e demais legislação aplicável, toda a cópia, parcial ou total, deste documento, nos casos em que é legalmente admitida, deverá conter ou fazer-se acompanhar por este aviso.

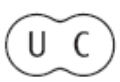




\title{
Incêndios florestais no distrito da Guarda. Fatores desencadeantes e consequências ambientais
}

\author{
Susete dos Anjos Henriques \\ Mestre em Geografia Física, Ambiente e Ordenamento do Território pela Faculdade de Letras da Universidade de Coimbra. \\ suseteanjos@hotmail.com
}

\section{Luciano Lourenço}

Departamento de Geografia e Centro de Estudos em Geografia e Ordenamento do Território (CEGOT). Faculdade de Letras da Universidade de Coimbra. luciano@uc.pt

\section{Resumo:}

Portugal tem sido fustigado, ao longo das últimas décadas, por numerosos incêndios florestais. A área ardida tem vindo a aumentar consideravelmente, sendo o país do Sul da Europa Mediterrânea com a maior percentagem de área queimada.

Ao examinarmos a distribuição geográfica das áreas ardidas, em termos de NUT's II, verificamos que a Região Centro tem sido a mais flagelada. Descendo a uma escala de mais pormenor, observa-se que o distrito da Guarda constitui o território mais afetado pelas chamas, motivo pelo qual centramos este estudo nesse espaço.

Pretende-se, pois, efetuar uma análise diacrónica da manifestação do risco dendrocaustológico no distrito da Guarda, no período compreendido entre os anos hidrológicos de 1980/81 e 2009/10, com o objetivo de perceber como se têm conjugado os fatores desencadeantes.

Por outro lado, após a ocorrência de incêndios florestais, registam-se mudanças na ocupação do solo, pelo que, outro dos objetivos, passa pelo estabelecimento das formas de evolução da paisagem.

Deste modo, com o presente estudo procura-se contribuir para uma melhor compreensão das diversas ações que interferem com o risco de incêndio florestal, assim como, se deseja analisar a nova paisagem que, progressivamente, vai ganhando terreno após a passagem dos incêndios florestais.

Palavras-chave: Risco dendrocaustológico. Distrito da Guarda. Regeneração da vegetação.

\section{Résumé:}

Les feux de forêt dans le district de Guarda. Les facteurs déclenchants et les conséquences environnementales

Le Portugal a été fustigé, au cours des dernières décennies, par de nombreux incendies de forêt. La surface brûlée a considérablement augmentée, en particulier dans les pays du Sud de l'Europe Méditerranéenne avec le pourcentage le plus élevé de la surface brûlée.

En examinant la répartition géographique des zones brûlées en termes de NUT II, nous constatons que le Centre du Portugal a été la région plus durement touchée. Jusqu’à une échelle plus détaillée, on observe que le district de Guarda est le territoire plus touché par les flammes, ce qui explique pourquoi cette étude se concentre dans cet espace.

L'objectif est donc de faire une analyse diachronique de la manifestation du risque dendrocaustologique dans le district de Guarda, dans la période des années hydrologiques 1980/81 et 2009/10, visant à comprendre comment il était la combinaison des facteurs déclencheurs.

D'autre part, après la survenance des incendies de forêt, il ya des changements dans l'utilisation des terres, de sorte que d'autres objectifs, est la mise en place des formes de l'évolution du paysage.

Ainsi, la présente étude vise à contribuer à une meilleure compréhension des différentes actions qui interfèrent avec le risque feu de forêt, ainsi que d'examiner le nouveau paysage qui gagne progressivement du terrain après le passage des feux de forêt.

Mots-clés: Risque dendrocaustologique. District de Guarda. Régénération de la végétation. 


\section{Abstract:}

Forest fires in the district of Guarda. Triggering factors and environmental consequences

Portugal has been fustigated, throughout the last decades, by numerous forest fires. The area burned has increased considerably and the country of Southern Mediterranean Europe with the highest percentage of area burned.

By examining the geographic distribution of burned areas, in terms of the NUT II, we find that the Central Region of Portugal has been the most plagued. Down to a scale of more detail, we observe that the district of Guarda is the territory most affected by the flames, which is why this study are focusing in this space.

The aim is, therefore, to make a diachronic analysis of the manifestation of the dendrocaustological risk in the study area, in the period between hydrological years $1980 / 81$ and $2009 / 10$, aiming to understand how it was the combination of the factors triggering.

On the other hand, after the occurrence of forest fires, there are changes in land use, so another of the objectives, is the establishment of forms of landscape evolution.

Thus, the present study seeks to contribute to a better understanding of the various actions that interfere with the forest fire risk, as well as, whether to examine the new landscape that gradually gaining ground after the passage of forest fires.

Keywords: Dendrocaustological risk. District of Guarda. Regeneration of vegetation.

\section{Introdução}

A elevada incidência do número de incêndios florestais e a dimensão da área ardida que se tem vindo a verificar no nosso país, são motivo de preocupação para todos nós. Todos os anos, sobretudo na época estival, somos confrontados com o alarmismo e com o drama destes acontecimentos. Com maior ou menor relevância, mas sempre com prejuízos de natureza diversa, este problema não só corresponde à perda de valor económico e cultural da nossa floresta, mas também ameaça, diversas vezes, os habitantes dos lugares afetados, assim como a segurança das populações e das forças que combatem os incêndios.

O fogo, é considerado um fenómeno que pode surgir naturalmente, como por exemplo, através de uma trovoada, contudo, na maior parte das vezes, é provocado pelo ser humano. Quando se inicia a primavera, é frequente ver os agricultores ou os pastores a proceder à limpeza dos solos agrícolas e florestais, através da execução de queimadas extensivas, para renovação das pastagens ou para limpeza dos terrenos, em que é lançado fogo ao combustível que está espalhado pelo terreno a renovar ou a limpar, como é o caso do restolho e do mato ou dos sobrantes de cortes, bem como da queima intensiva de combustíveis florestais, cortados e amontoados, mas em que a combustão tem lugar num espaço limitado e de reduzidas dimensões (CARVALHo e Lopes, 2001: 30-31). Devido a tais situações e a outras, em que os atuantes agem de forma negligente ou intencional, assistimos periodicamente a incêndios que por vezes têm dimensões assustadoras.

A percepção de uma variada gama de interações, entre os sistemas de gestão antrópica e as componentes físicas do território, constitui matéria científica de elevada importância para a disciplina de Geografia, uma vez que os seus principais objetivos são os de conhecer, compreender e saber interpretar as inter-relações entre fatores humanos e naturais.

Desta forma, achámos pertinente a elaboração deste estudo para tentarmos perceber a razão de ser de tão elevado número de ocorrências de incêndios florestais, assim como da vasta área ardida registada no distrito da Guarda. Pretende-se, assim, efetuar uma análise diacrónica da manifestação do risco dendrocaustológico nesta área de estudo, no período compreendido entre os anos hidrológicos de 1980/81 e 2009/10.

Após a ocorrência de incêndios florestais, surgem, entre outras, preocupações ambientais, algumas das quais se traduzem em mudanças na ocupação do solo, sendo possível estabelecer diversas formas de evolução da paisagem. Por isso, o trabalho de campo efetuado para a realização deste estudo, incidiu sobretudo na observação da regeneração da vegetação após os incêndios florestais.

Deste modo, com o presente estudo procura contribuir-se para uma melhor compreensão de diversas interações na sua relação com o risco de incêndio florestal, assim como, se deseja analisar a nova paisagem que, progressivamente, vai ganhando forma após a passagem dos incêndios florestais.

\section{Área de Estudo}

A área sobre a qual incide o presente estudo corresponde, em termos administrativos, ao distrito da 
Guarda, que integra 14 municípios: Aguiar da Beira, Almeida, Celorico da Beira, Figueira de Castelo Rodrigo, Fornos de Algodres, Gouveia, Guarda, Manteigas, Meda, Pinhel, Sabugal, Seia, Trancoso e Vila Nova de Foz Côa.

A maior parte desta área de estudo situa-se no Interior da Região Centro (NUT II) de Portugal Continental, numa unidade territorial específica, a Beira Interior Norte (NUT III), à exceção dos municípios de Aguiar da Beira, pertencente à NUT III Dão Lafões, de Fornos de Algodres, Gouveia e Seia, os quais pertencem à NUT III Serra da Estrela e do município de Vila Nova de Foz Côa, que faz parte da Região Norte (NUT II) e da NUT III Douro (Figura 1).

\section{Metodologia}

A metodologia utilizada na execução deste trabalho baseia-se na consulta de bibliografia diversa e de outros documentos de base, na pesquisa de informação numérica variada, assim como no recurso a suportes informáticos para a pesquisa de informação, através da internet, complementada com aturado trabalho de campo. Os resultados obtidos expressam-se através de quadros, gráficos e de cartografia temática.

O trabalho de campo consistiu no levantamento do grau de cobertura do solo pelas espécies vegetais em regeneração, bem como da evolução do seu crescimento, após o incêndio de Agosto de 2010, especificamente no período de tempo que decorreu entre outubro de 2010 e julho de 2011.

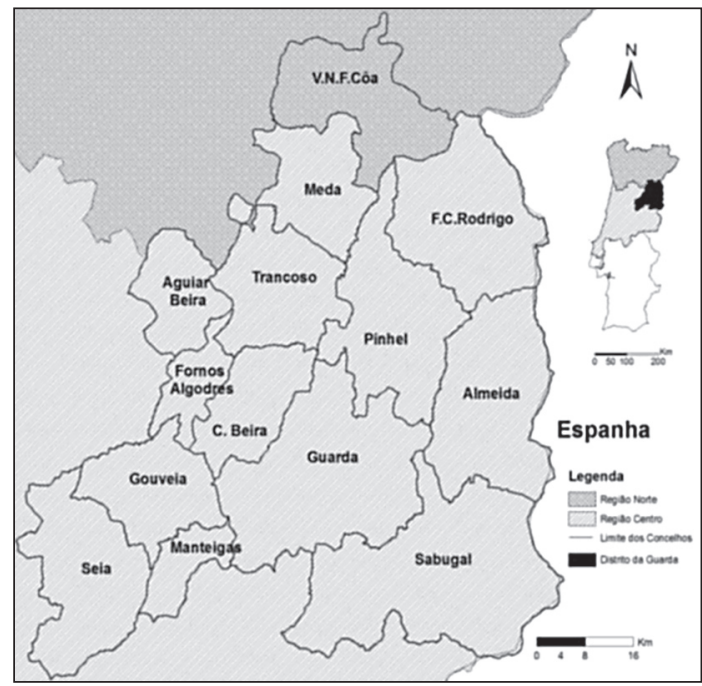

Figura 1

Localização dos concelhos do distrito da Guarda e sua relação com as NUT.
Para esse efeito, construiu-se uma estrutura em madeira, com a dimensão de $1 \mathrm{~m}^{2}$, ou seja, com $1 \mathrm{~m}$ de lado, dividida em quadrículas de $100 \mathrm{~cm}^{2}$, isto é, com $10 \mathrm{~cm}$ de lado. Aplicou-se uma vez por mês, entre outubro de 2010 e julho de 2011, exceto em junho, devido a uma situação imprevista e de que não decorreu grande prejuízo, uma vez que, em regra, a vegetação já se encontrava a retomar um estádio evolutivo mais lento.

A aplicação desta quadrícula decorreu em locais previamente selecionados que, entre outros fatores, tiveram em linha de conta a morfologia do terreno, a orientação das vertentes, o uso e ocupação do solo, assim como o tipo de vegetação existente. Esta evolução foi acompanhada de aturado registo fotográfico, alguns dos quais servem de suporte ao texto e, simultaneamente, de prova documental.

\section{Suscetibilidade da área de estudo a incêndios florestais}

A elevada suscetibilidade a incêndios florestais apresentada pela área de estudo decorre, essencialmente, da falta de gestão do espaço florestal, a qual, por sua vez, é consequência de profundas transformações que a sociedade portuguesa passou a viveu a partir da última metade do século XX.

Através da análise da variação da população residente, entre 1950 e 2011, verifica-se que toda a área de estudo perdeu muitos habitantes neste período, um fenómeno característico de todo o interior do país, a que a região da Beira Interior não escapou e a que o distrito da Guarda também não foi exceção sendo, até, um dos mais atingidos por este processo de despovoamento. Os meios rurais foram os mais afetados pela saída da população, primeiro para o estrangeiro e, depois, em direção aos centros urbanos, aos centros de decisão e poder, quer no seio do município, do distrito ou dos maiores centros urbanos do país.

$O$ processo de emigração que se acentuou a partir dos anos sessenta do século XX deu azo a uma série de consequências que colocaram esta parte do território numa situação económico-social, política e estrutural desvantajosa em relação ao litoral. Note-se que os concelhos onde se regista maior perda demográfica são, precisamente, os concelhos que se localizam mais no interior do distrito, tais como, o do Sabugal, aquele que, de entre todos os concelhos, mais população perdeu, com um registo negativo de $71 \%$, seguido pelos concelhos de Meda (-62\%), Almeida (-59\%), Figueira de Castelo Rodrigo (-58\%), Pinhel e Vila Nova de Foz 
Côa (-57\%). Os restantes concelhos denotam, da mesma forma, uma variação negativa bastante acentuada, registando-se a menor perda nos concelhos de Seia e da Guarda, mesmo sendo este a sede do distrito, onde a variação negativa foi superior a -30\% (Figura 2).

É também de salientar a associação entre as maiores perdas demográficas e a maior área dos respetivos concelhos, isto é, são os detentores de maiores dimensões aqueles que são também os mais abrangidos pelo processo de despovoamento, designadamente o Sabugal, o maior de todos, Figueira de Castelo Rodrigo, Almeida e Pinhel.

Como consequência do êxodo rural e da forte emigração registada nestes espaços do interior e, também, de fronteira, a população ativa e em idade fértil têm um peso diminuto nesta área, o que tem consequências a diferentes níveis e, entre outros, se refletem no abandono da atividade agrícola e dos campos, na falta de gestão do espaço florestal e na indisponibilidade de efetivos para combater incêndios florestais.

Na Europa Mediterrânea, o colapso do antigo sistema agrário tradicional teve início entre o fim do século XIX e princípios do século XX (A. NUNES, 2007), embora com diferenças significativas nas escalas temporal e espacial destes acontecimentos. Assim, nos países do Sul da Europa, até meados do século XX, permaneceu um processo de intensificação da agricultura nas terras com mais potencialidades produtivas (introduziu-se o sistema de rotação de culturas, sem pousio, por forma a retirar o máximo proveito das terras) e, concomitantemente, a extensificação das formas de produção e o

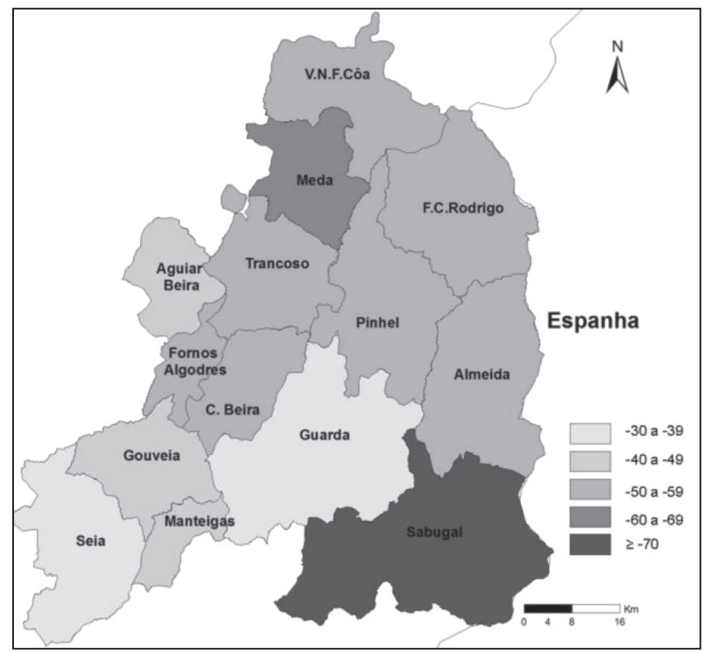

Figura 2

Variação da população residente no distrito da Guarda (\%) entre 1950 e 2011, por concelho, com base nos dados do IX Recenseamento Geral do População (1950) e Censos 2011, INE. abandono dos espaços mais desfavorecidos, do ponto de vista natural, económico e estrutural.

A partir de meados do século XX, o desenvolvimento dos centros urbanos contribuiu para o êxodo rural, devido à decadência dos espaços rurais, e conduziu ao abandono físico do território, que se manifestou por um acentuado declínio, ou até mesmo, nalguns casos, pelo total desaparecimento das atividades agro-silvopastoris, que até essa altura eram essenciais para o autoconsumo e sobrevivência dos habitantes rurais (NunEs, 2002/04). De certo modo, as terras produtoras de cereais, as pastagens e outras culturas permanentes foram, paulatinamente, sendo desprezadas, como consequência dos débeis recursos económicos obtidos e da necessidade de muita mão-de-obra, que deixou de estar disponível e não fora substituída por mecanização, pelo que se apresentava bastante deficitária.

Por sua vez, o pastoreio, que desempenhava uma importância ativa nos sistemas agrários tradicionais, e com um papel importante na redução dos combustíveis rasteiros, também sofreu alterações. As intensas modificações demográficas registadas nos territórios de montanha, foram também acompanhadas por um acentuado decréscimo do gado ovino e caprino, uma vez que a população ativa que neles permaneceu foi transferindo a sua atividade para os setores secundário e, sobretudo, terciário (NUNES, 2007).

Como consequência desta conjuntura, vão surgindo, ao longo do tempo, sinais evidentes da deserção física ocorrida no espaço agrário, através da observação de uma paisagem modificada e mais verdejante. A florestação planeada de espaços com aptidão agrí cola que, entretanto, tinham sido desprezados, ou a sua reflorestação espontânea e a consecutiva expansão florestal, são os indícios mais evidentes das mudanças do uso do solo ocorridas nestes últimos anos (CONTI e FAGARAZZI, 2004)

0 mundo rural reflete os modos de adaptação das sociedades aos condicionalismos do meio geográfico. Desta forma, tornou-se essencial conhecer os diferentes ritmos de evolução da população desta área de estudo, uma vez que nos ajudam a compreender a configuração atual destes territórios. Os agentes que mais contribuíram para o atual cenário de desequilíbrio nestas áreas de interior são de origem diversa, mas, entre eles, destaca-se claramente o êxodo rural, que, consequentemente, levou à falta de manutenção da atividade agrícola e à deterioração geral das paisagens.

Embora o êxodo rural seja justificado pela procura de melhores condições de vida, acabou por provocar profundas alterações nas estruturas socioeconómica, 
etária e profissional dos residentes desta área de análise, as quais se fizeram repercutir negativamente no binómio agricultura-floresta (LOURENÇO, 2006).

Por outro lado, os incêndios florestais também têm contribuído para tornar estas áreas ainda mais repulsivas, dado que o espaço ocupado por terrenos incultos viu a sua área aumentar drasticamente desde 1974, em quase toda a área de estudo, com maior relevância nos concelhos de Celorico da Beira, Fornos de Algodres, Gouveia, Guarda, Sabugal e Seia. Com uma variação negativa destaca-se, apenas, o município de Vila Nova de Foz Côa (Figura 3).

Do mesmo modo, quando analisamos a percentagem da variação da área florestal, averiguamos que a floresta regrediu de uma forma intensa na maior parte dos concelhos. A principal exceção correspondeu ao município de Vila Nova de Foz Côa, que registou acréscimo na representatividade das várias espécies analisadas (Pinus pinaster, Quercus pyrenaica, Eucalyptus globulus e Quercus rotundifolia), provavelmente por conter o Parque Arqueológico do Vale do Côa e este estar sob medidas de proteção de áreas com elevado interesse patrimonial e paisagístico, o que comprova ser possível inverter a atual tendência de absentismo, que conduz à degradação da paisagem, e, deste modo, proteger algumas das espécies florestais mais ameaçadas pelo fator abióticos que os incêndios florestais constituem, aumentando-se, assim, a ocupação do solo e a produção florestal (Figura 4).

De entre todas, a espécie florestal com maior predominância na área de estudo ainda é o pinheiro

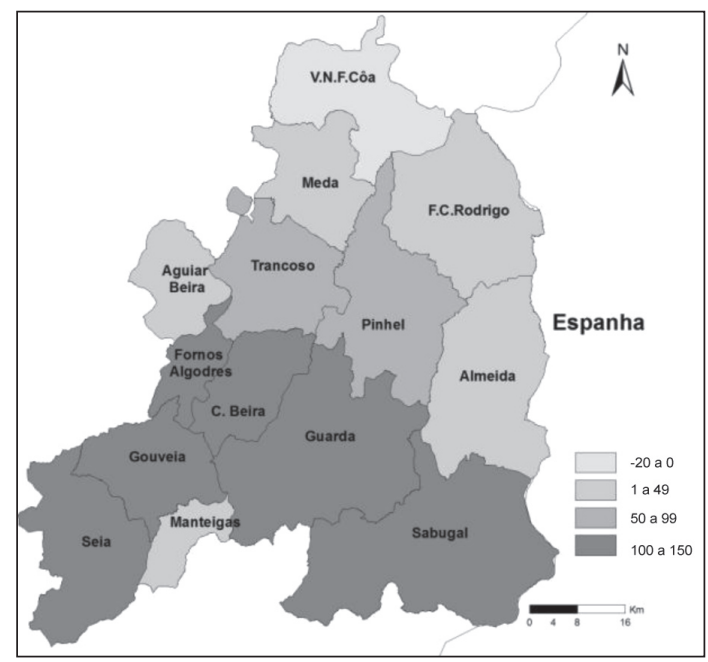

Figura 3

Variação, em percentagem, do espaço ocupado pelos incultos na área de estudo, entre 1974 e 2004-06, baseada nos inventários florestais da AFN.

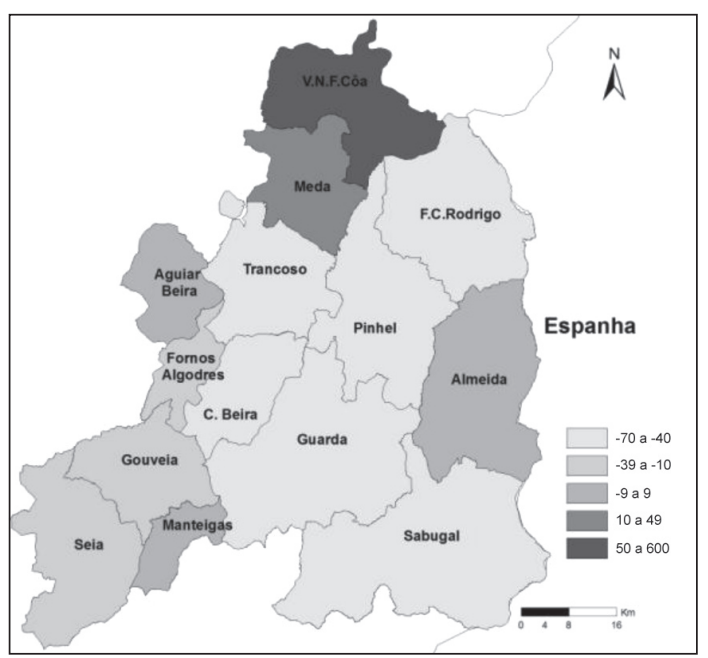

Figura 4

Variação percentual da área florestal na área de estudo entre 1974 e 2004-06, com base nos inventários florestais da AFN.

bravo (Pinus pinaster), embora, nos últimos anos, a sua área de ocupação tenha vindo a diminuir. Por exemplo, no concelho de Seia, ocupava cerca de 20000 ha, em 1974, mas, em 2004-06, a sua área estava confinada a pouco mais de 4000 ha. Atualmente, Aguiar da Beira é o município que detém a maior área florestal desta espécie, cerca de 8000 ha. Os concelhos que sofreram maiores alterações na variação desta espécie foram os de Seia, Sabugal, Guarda, Celorico da Beira, Fornos de Algodres e Gouveia, seguidos pelos municípios de $\mathrm{Pi}$ nhel, Meda, Trancoso e Manteigas. Apenas os concelhos

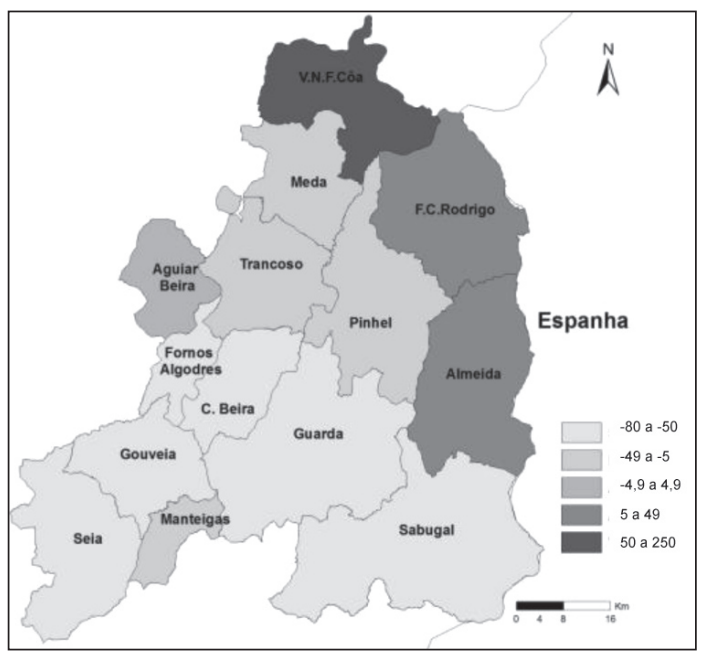

Figura 5

Variação do pinheiro-bravo (Pinus pinaster) na área de estudo (\%), entre 1974 e 2004-06. Dados retirados dos inventários florestais da AFN. 


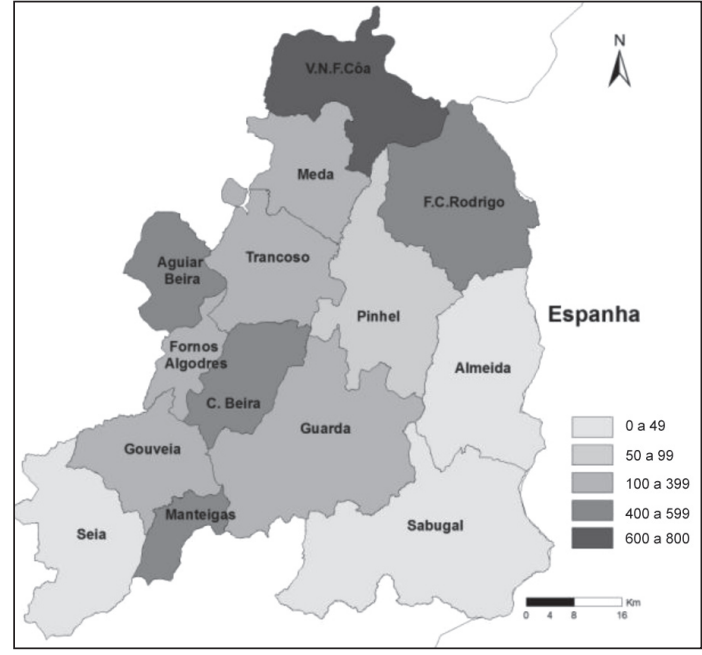

Figura 6

Variação do carvalho (Quercus pyrenaica) na área de estudo (\%), entre 1974 e 2004-06. Dados retirados dos inventários florestais da AFN.

de Almeida, Figueira de Castelo Rodrigo e Vila Nova de Foz Côa registaram acréscimo de área ocupada por pinheiro bravo (Figura 5).

O carvalho negral (Quercus pyrenaica) é outra das espécies florestais mais representativas da área de estudo e, ao contrário do pinheiro bravo, aumentou a sua área de abrangência em todos os concelhos, ou seja, apresentou uma variação positiva em toda a área de estudo, porque está bem adaptada edafoclimaticamente e é bastante resistente aos incêndios florestais. A sua maior representatividade diz respeito aos concelhos de Manteigas, Celorico da Beira, Aguiar da Beira, Figueira de Castelo Rodrigo e, sobretudo, Vila Nova de Foz Côa (Figura 6). Esta espécie tem sido salvaguardada não só pela sua capacidade de regeneração após os incêndios, mas também pelo seu interesse, patente na valorização da produtividade do potencial lenhoso dos povoamentos de folhosas autóctones e na preservação de áreas florestais naturais e seminaturais, integradas na Rede Nacional de Áreas Protegidas, ou na Rede Natura 2000, como é o caso do Vale do Côa ou da Serra da Malcata.

A manifestação do risco dendrocaustológico em análise diacrónica (1981 - 2010)

Ao longo das três últimas décadas (1981-2010), a área ardida nos povoamentos florestais do distrito da Guarda teve grandes oscilações, registando vários anos com valores bem superiores à média, como sucedeu em 1985, 1990, 2003, 2005 e, mais recentemente, em 2010. É notória uma certa tendência para a diminuição da área florestal queimada e, em contrapartida, para aumento da área ardida em formações herbáceas e arbustivas, mais vulgarmente designadas por mato, uma vez que algumas das espécies florestais não têm capacidade de regeneração natural, face à reincidência de incêndios, e, por conseguinte, depois destes não geram novos povoamentos florestais. De facto, na década de 80 , só o ano de 1985 registou mais de 25000 ha de matos queimados, enquanto que nas duas décadas seguintes, houve dois anos, 1994 e 1998, bem como 2000 e 2003, com área de mato queimada superior a esse valor (Figura 7).

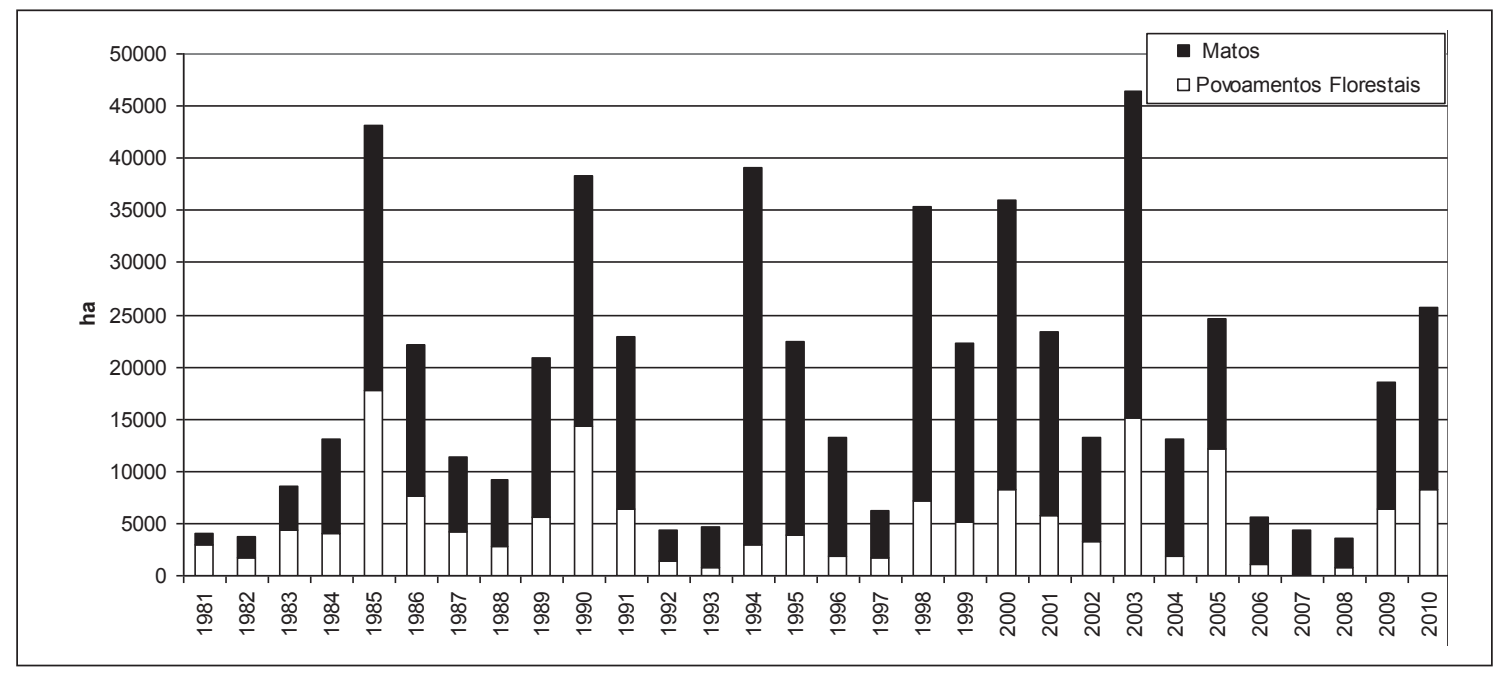

Figura 7

Evolução anual da área ardida (ha) em povoamentos florestais e em mato, no distrito da Guarda, entre 1981 e 2010, com base em dados estatísticos da AFN. 


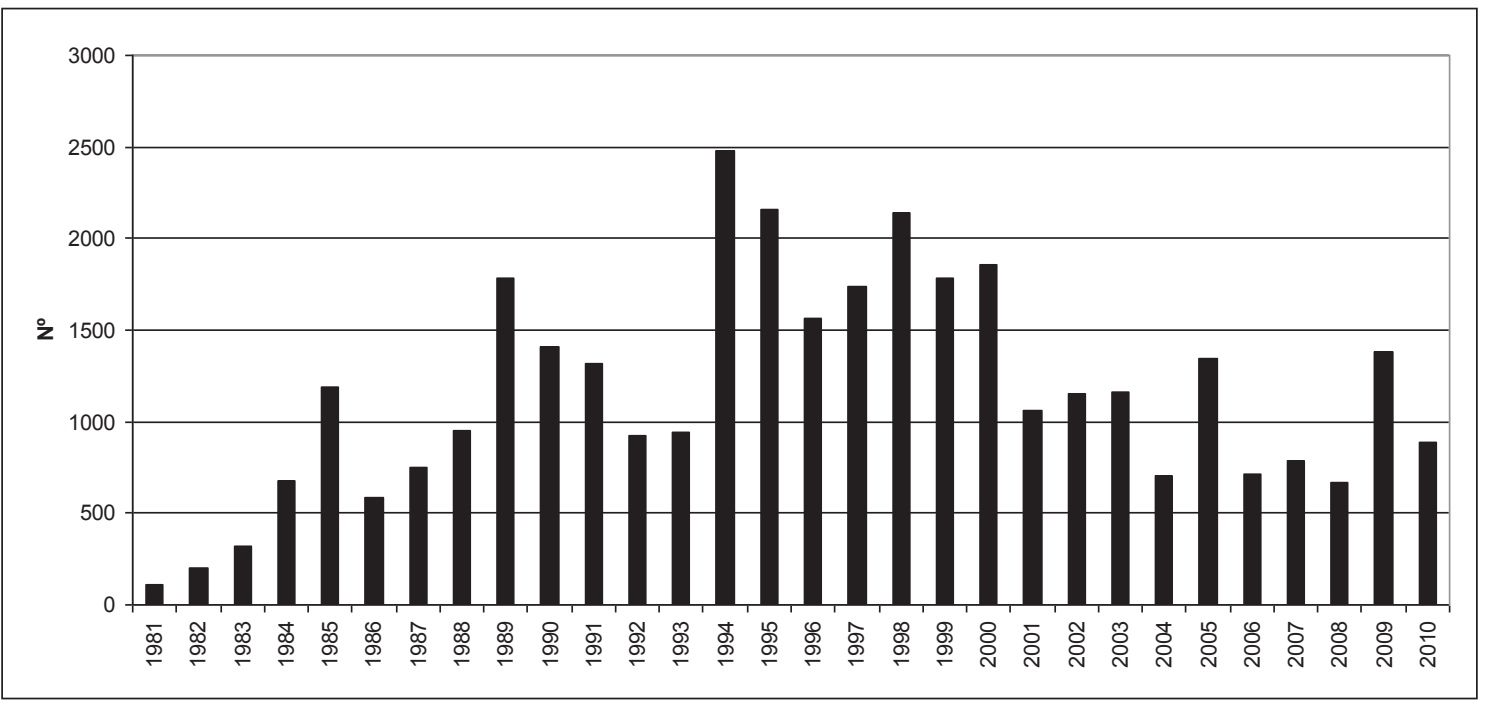

Figura 8

Evolução anual do número de ocorrências de incêndios florestais, no distrito da Guarda, entre 1981 e 2010, com base em dados da AFN.

No que diz respeito ao número de ocorrências de incêndios florestais, verificou-se uma certa tendência para o seu aumento, até ao final do século passado, a que se seguiu uma significativa redução no início deste milénio, com quase $50 \%$ de 2000 para 2001, mas que, porventura, até se poderá considerar anterior, na medida em que 1994 foi o ano que mais se salientou, por ter registado cerca de 2500 ocorrências (Figura 8).

\section{A desigual sensibilidade dos concelhos do distrito da Guarda aos incêndios florestais}

A distribuição geográfica do número de incêndios florestais e das respetivas áreas ardidas, em cada um dos municípios do distrito da Guarda, permite verificar uma certa diferenciação entre eles, em função da sua maior ou menor sensibilidade ao fogo, a qual pode ser traduzida em duas componentes complementares: a primeira delas, ligada ao risco de ignição, reflete a densidade média anual de ocorrências, enquanto a segunda, mais associada ao perigo de progressão, traduz a percentagem média de área ardida anualmente em relação à respetiva superfície municipal.

Ora, da análise efetuada à distribuição geográfica das ocorrências de incêndios, ficou clara a existência de alguns municípios especialmente favoráveis à ignição de incêndios e que, por conseguinte, registaram um elevado número de ocorrências anuais, como sucedeu nos concelhos da Guarda, Gouveia, Sabugal e Seia (Figura 9). Além disso, sobretudo dois destes concelhos,
Guarda e Sabugal, mas também o de Seia, registaram também uma elevada média de área ardida anual (Figura 10), pelo que, além do elevado número de ignições, a facilidade de progressão dos incêndios nesses concelhos é preocupante e merece ser analisada.

Todavia, esta distribuição dá uma ideia errada da severidade dos incêndios nos diferentes concelhos, uma vez que os municípios de maior dimensão têm probabilidade de registar maior número de ocorrências e maior área ardida do que os mais pequenos, pelo simples facto de uns serem maiores do que os outros. Deste modo, se em vez de considerarmos a totalidade das ocorrências e da área ardida em cada concelho, as relacionarmos com a respetiva superfície municipal, veremos que a geometria espacial antes descrita se altera substancialmente.

Com efeito, a maior densidade de ocorrências registou-se nos concelhos de Trancoso, Meda, Fornos de Algodres, Celorico da Beira, Seia e Gouveia, abrangendo toda a área ocidental do distrito, com exceção de Aguiar da Beira (Figura 11), deixando de fora os concelhos da Guarda e Sabugal que, em função da respetiva área municipal, ganhavam preponderância na anterior situação.

Por sua vez, o município da Guarda mantém a maior percentagem de área ardida, acompanhado pelo de Gouveia, que subiu duas posições, mas, em contrapartida, o do Sabugal desceu para segundo lugar, posição que partilha com os municípios de Seia, que não sofreu alteração, e de Fornos de Algodres, que também subiu dois lugares. Deste modo, a maior percentagem de área ardida concentra-se nos municípios do Sul do 


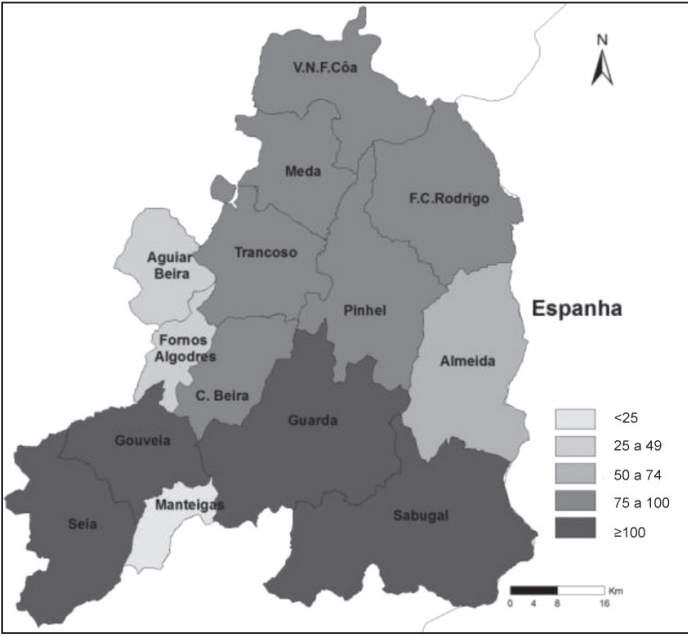

Figura 9

Média anual de ocorrências de incêndios florestais, nos concelhos do distrito da Guarda, entre 1981 e 2010, a partir dos dados da AFN.

distrito, com exceção do concelho de Manteigas (Figura 12).

Quando se procura explicar a incidência e a dimensão dos incêndios que ocorrem na área de estudo, as características mediterrâneas do clima assumem, de imediato, um papel de destaque, ressaltado por diversos autores que sobre este tema se têm debruçado, designadamente Rebelo (1980), Lourenço (1988, 1992), Cunha e Gonçalves (1994), Nunes (2000) e Pausas (2004), uma vez que é nas condições meteorológicas mais severas que, normalmente, se têm desenvolvido os incêndios de maiores dimensões.

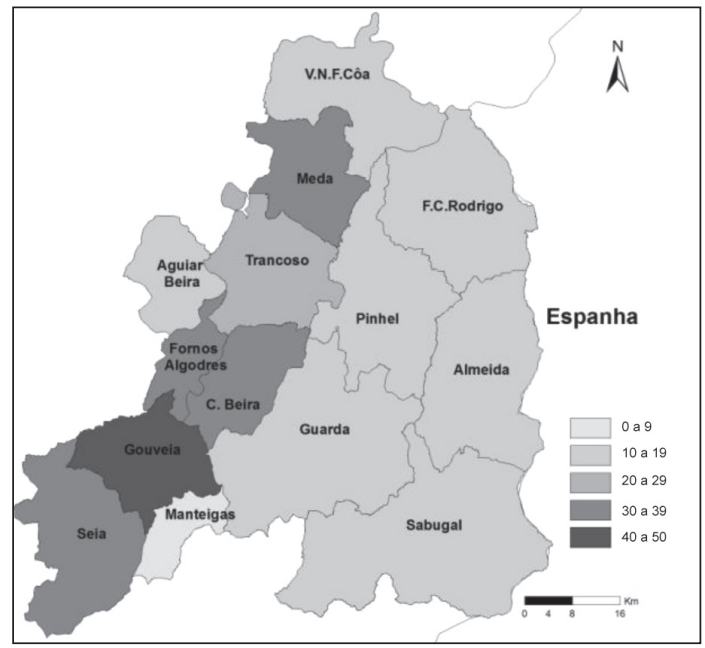

Figura 11

Densidade média anual de ocorrências de incêndios florestais por 100 km² de superfície municipal, entre 1981 e 2010 , nos concelhos do distrito da Guarda, baseada em dados estatísticos da AFN.

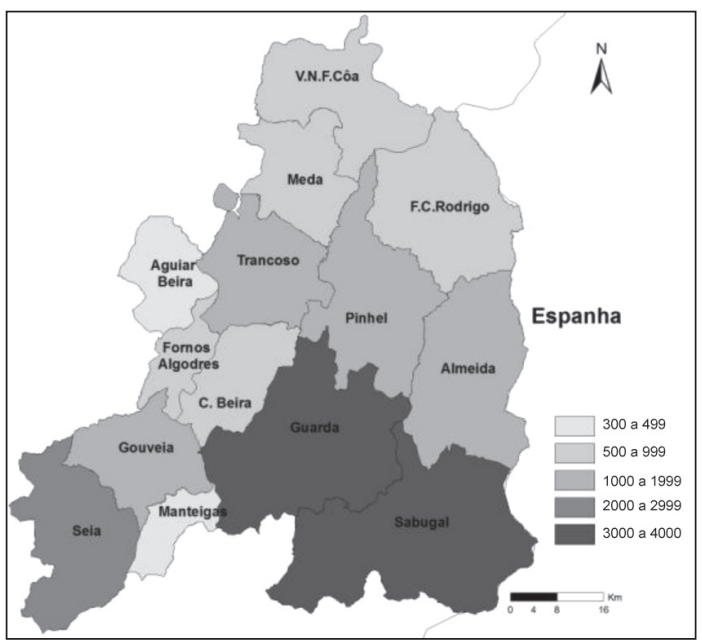

Figura 10

Média anual da área ardida (ha), nos concelhos do distrito da Guarda, entre 1981 e 2010, a partir dos dados da AFN.

De facto, as situações meteorológicas simultaneamente favoráveis à ignição e propagação dos incêndios, que se manifestam através de elevadas temperaturas e baixos valores da humidade relativa do ar, conjugadas com a ocorrência de vento, sobretudo do quadrante Este e acompanhado de rajadas fortes, determinam as situações mais críticas em termos de incêndios florestais (Lourenço, 1988 e 2007), como se verificou, pela última vez, no ano de 2010 (Henriques, 2011: 77).

Todavia, as condições meteorológicas apenas facilitam a ignição e propagação, pois só muito raramente, em situação de trovoada seca, constituem causa de

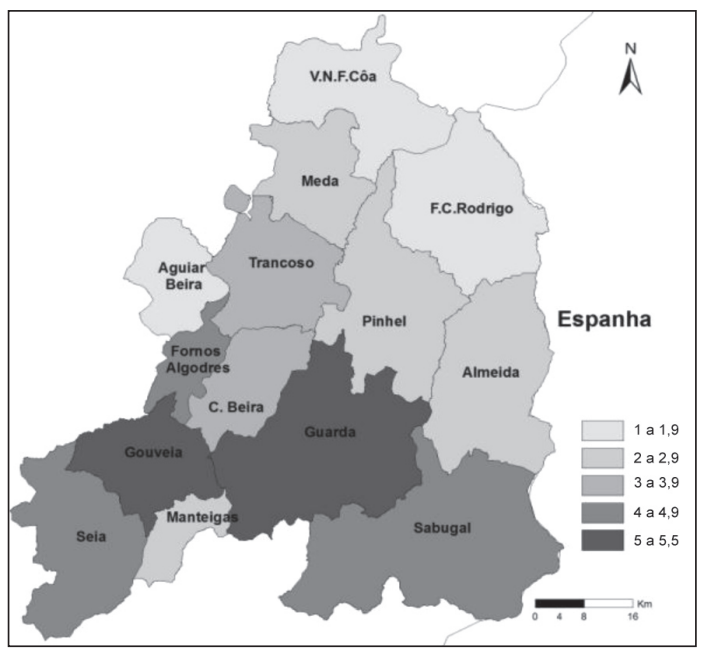

Figura 12

Percentagem média anual de área ardida relativamente à superfície municipal, entre 1981 e 2010, nos concelhos do distrito da Guarda, baseada em dados estatísticos da AFN. 
incêndio florestal, pelo que a origem de tão elevado número de ocorrência só poderá ser de natureza humana, voluntária ou não.

De todas as formas, tanto na ignição como na propagação dos incêndios florestais, intervêm numerosos fatores, desde as condicionantes físicas até aos recursos humanos e materiais envolvidos no combate às chamas, passando pela (in)existência de prevenção estrutural, pelo que a análise dos incêndios florestais é complexa e cada caso deve ser estudado individualmente.

A generalizada falta de gestão do espaço florestal, que permite a acumulação de grande quantidade de combustível, o qual, devido à elevada reincidência de incêndios florestais, é, em muitos casos, constituído quase exclusivamente por mato, acaba por ser a grande causa indireta dos incêndios florestais e que, dada a ausência de valor económico do mato, ajuda a explicar a dimensão das áreas ardidas.

Esta falta de gestão decorre de múltiplos fatores, a que não foi alheio o êxodo rural e as suas consequências, traduzidas na diminuição e envelhecimento da população, na substancial redução da atividade agrícola, bem como da pastorícia e da exploração florestal, até às alterações na estrutura socioeconómica da população residente.

\section{A regeneração da vegetação após os incêndios: estudo de caso em 2010}

Para melhor caracterizar a vegetação do distrito, em termos da representatividade das diferentes espécies, o mais lógico teria sido escolher áreas-amostra em cada um dos grandes incêndios florestais de 2010, registados no distrito da Guarda, mas não foi isso que aconteceu.

Com efeito, circunstâncias de natureza financeira condicionaram as opções á proximidade da residência, pelo que as que seis áreas-amostra escolhidas $\left(A_{1}, A_{2}\right.$, $B, C, D$ e E) localizaram-se num dos maiores incêndios registados em 2010, que consumiu 5058 ha, entre 26 de agosto, dia em que teve início, nas Quintas de Gonçalo Martins, Penedo da Sé, concelho da Guarda, e o dia 29, quando terminou, na Malhada Sorda, concelho de Almeida (Figura 13).

Assim, as áreas-amostra apresentam a seguinte caraterização sumária:

- $A_{1}$ e $A_{2}$ - Localizam-se em Peroficós, concelho do Sabugal, num terreno que deixou de possuir atividade agrícola há cerca de vinte anos, havendo ainda vestígios de ser lavrado com arado de vacas, para o cultivo de cere-

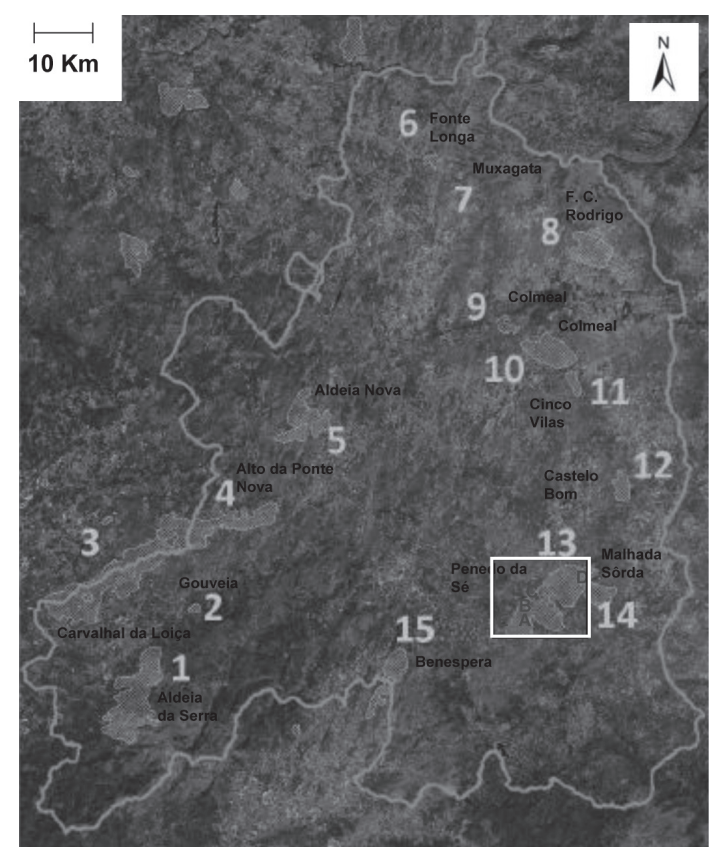

Figura 13

Localização das principais áreas ardidas no distrito da Guarda, entre janeiro e setembro de 2010

Área de estudo.

ais, nomeadamente, de centeio. Atualmente são pastadas por gado ovino. O terreno é permeável e apresenta solo espesso, embora com alguns afloramentos rochosos, sendo plano em $A_{1}$ e possuindo um declive aproximado de $10^{\circ}$, em $A_{2}$. A vegetação restringe-se à presença de algumas árvores (carvalhos - Quercus pyrenaica), muitos arbustos (giesta branca - Cytisus multiflorus e bracejo - Festuca sp.) e diversas herbáceas.

- B - Localiza-se, também, em Peroficós e situase junto a uma sebe, numa área de pastagem (utilizada para gado ovino), em vertente voltada a Oeste, com declive de $20^{\circ}$, aproximadamente, solo pouco espesso, pouco permeável e com alguns afloramentos rochosos, sujeito a escorrência e erosão. Fica situada sob a copa de freixos (Fraxinus angustifolia) e a vegetação circundante é dominada por espécies arbóreas (Quercus pyrenaica e Fraxinus angustifolia) e herbáceas.

- C - Situada perto do entroncamento entre a Miuzela e a Cerdeira do Côa, no concelho do Sabugal, numa área de pinhal que se desenvolve em terreno plano, solo espesso e permeável. 
- D - Localiza-se em Porto de Ovelha, concelho de Almeida, numa área de granito alterado, numa vertente voltada a Norte, com cerca de $40^{\circ}$ de declive e com bastantes afloramentos rochosos, num solo pouco espesso e pouco permeável, propício a erosão. A vegetação predominante do estrato arbóreo é constituída por Quercus pyrenaica, enquanto que a arbustiva é formada por Cytisus multiflorus, Cytisus striatus e Festuca sp. e, junto ao solo, dominam as herbáceas.

- E - Localiza-se no Penedo da Sé, concelho da Guarda, e corresponde a uma área de pastagem. Trata-se de um terreno plano, com solo espesso, permeável e com alguns afloramentos rochosos. A vegetação existente corresponde a Quercus pyrenaica, Fraxinus angustifolia, Cytisus multiflorus e herbáceas. Na área amostra apenas persiste vegetação herbácea.

\section{Evolução das diversas espécies vegetais}

Do ponto de vista do domínio fitogeográfico, as áreas-amostra monitorizadas enquadram-se no Sector Lusitano-Duriense, da Região Mediterrânea. Esta é uma área predominantemente granítica e de clima sub-húmido. Os bosques climatófilos enquadram-se no Genisto falcatae-Quercetum pyrenaicae, sendo as suas etapas de substituição mais evidentes traduzidas pelos giestais de Lavandulo sampaioanae-Cytisetum multiflori e os urzais de Halimietum alyssoido-ocymoidis e do Genistello tridentatae-Ericetum aragonensis (COSTA et al., 1998).
Estas espécies vegetais e a cobertura do solo refletem fielmente a dinâmica da vegetação depois da perturbação causada pela passagem do fogo, como nos foi dado observar.

Com efeito, verificou-se que, após o incêndio, a vegetação regenerou com relativa facilidade. Assim, a seguir às primeiras chuvas, sensivelmente dois meses depois do incêndio, ou seja, no mês de outubro, o solo começou a ficar preenchido pelos novos rebentos de vegetais ou pela germinação de algumas sementes. Nos meses seguintes e até ao final do inverno, manteve-se uma certa estagnação da cobertura do solo e, só depois, na estação primaveril, se notou um elevado acréscimo de vegetação.

$A$ área amostra mais preenchida foi a $B$, seguindo-se a $\mathrm{E}, \mathrm{A}_{1}, \mathrm{D}, \mathrm{A}_{2} \mathrm{e}$, em último lugar, a área $\mathrm{C}$. Esta corresponde a uma área de pinhal, onde a vegetação apenas se começou a regenerar e a desenvolver a partir do mês de fevereiro. Por sua vez, a área $B$ foi a única a preencher a totalidade do espaço quantificado, corres pondente a $1 \mathrm{~m}^{2}$ (Figura 14)

Assim, começando pelo crescimento das herbáceas, observou-se uma certa estagnação durante o final do outono e o período de inverno, pois só a partir do mês de abril, começou a evoluir favoravelmente, ainda que, na área-amostra $B$, tivesse havido um ligeiro crescimento até janeiro, com paragem em fevereiro e, a partir deste mês, voltasse a aumentar até maio. A partir do mês de maio, o crescimento das herbáceas variou em função de diversas circunstâncias. Assim, nas amostras $B$ e $A_{2}$, o crescimento diminuiu, devido ao avanço do estado de emurchecimento, enquanto que, nas amostras $\mathrm{E}, \mathrm{C}$ e $\mathrm{A}_{1}$, aumentou consideravelmente,

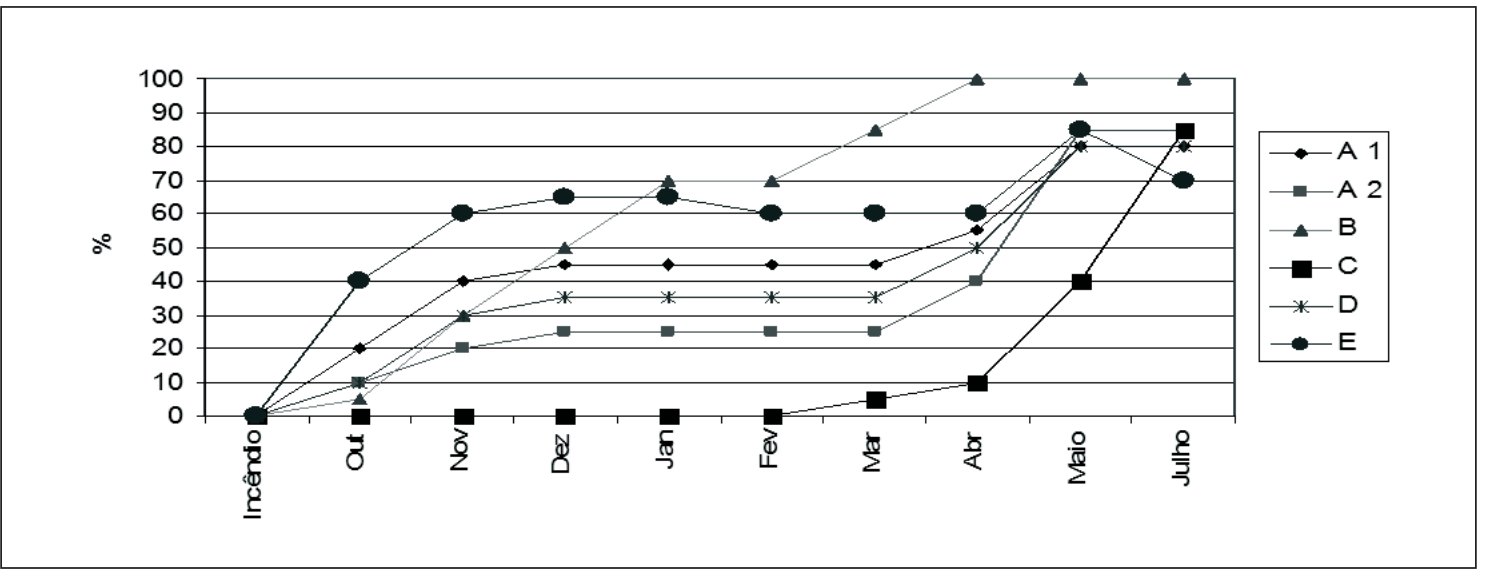

Figura 14

Evolução da cobertura do solo nas diversas áreas amostra estudadas. 


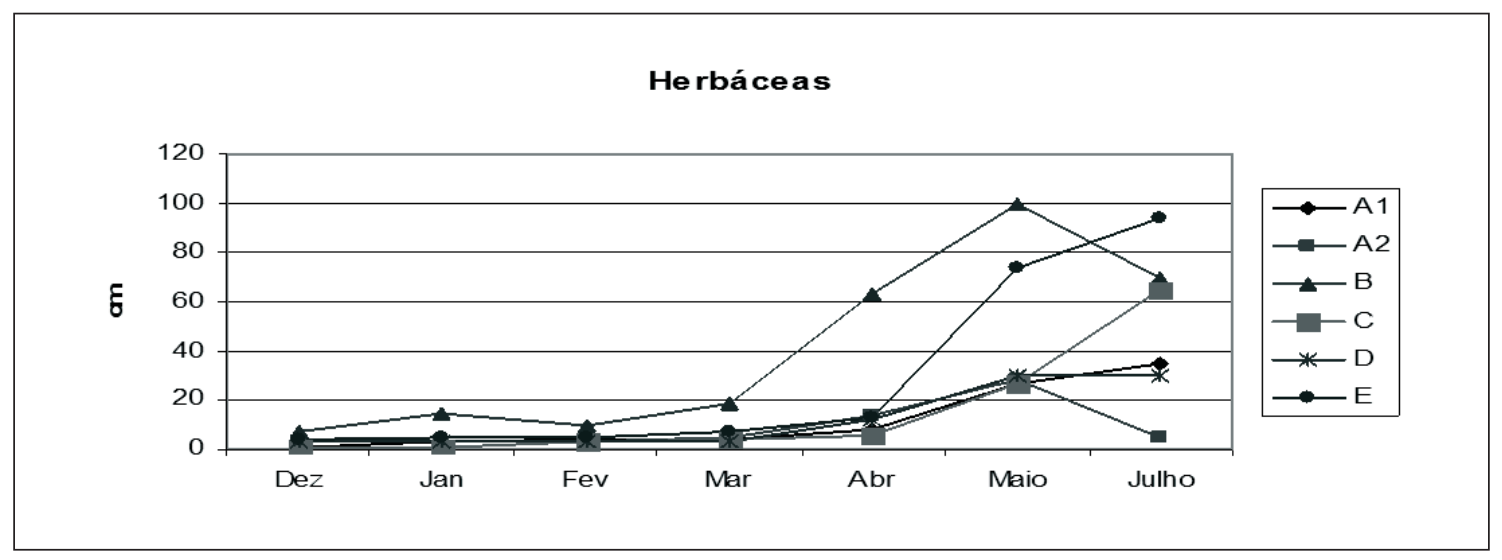

Figura 15

Evolução do crescimento das herbáceas nas diversas áreas-amostra.

ao passo que, na amostra $D$, se manteve estagnado. De qualquer forma, a área-amostra $B$ foi a que mais se destacou no crescimento das herbáceas, talvez por se situar numa vertente virada a Oeste e constituir uma área de pastagem (Figura 15).

No que diz respeito ao bracejo, esta espécie manteve, até ao mês de abril, o mesmo estado vegetativo nas três áreas-amostra $\left(A_{1}, A_{2}\right.$ e $\left.D\right)$. Em abril e maio, desenvolveu-se com grande vigor, tendo crescido $2 \mathrm{~m}$, na área $\mathrm{A}_{2}$, e $2,5 \mathrm{~m}$ nas áreas $\mathrm{A}_{1}$ e $\mathrm{D}$. Nos meses de junho e julho, estabilizou o seu estado de crescimento em todas as áreas-amostra, pelo que o seu desenvolvimento foi semelhante em todo o território estudado (Figura 16 e Fotografia 1).

Já o mesmo não sucedeu com as giestas que, na área-amostra $D$, rebentaram no mês de dezembro, enquanto na área $A_{1}$ apenas rebentaram em fevereiro e, em $A_{2}$, somente em março. Este atraso na rebentação das áreas A poderá dever-se ao facto do solo se ter mantido saturado em água durante o mês de janeiro e, sobretudo, devido à presença de geada, que nesta área apresentou grande frequência. A partir do mês de março, as giestas aumentam o seu tamanho em todas as áreas-amostra, com maior crescimento e vigor a partir do mês de abril, especialmente na $A_{1}$ (Figura 17 e Fotografia 2).

No que diz respeito ao crescimento dos rebentos de árvores, as diferenças são mais significativas. Como as outras espécies vegetais, também estas estagnaram no período invernal e começaram a desenvolver-se a partir da primavera. De entre elas, a espécie que mais se desenvolveu foi o carvalho, sobretudo na área-amostra D. O freixo, apesar de ter sido o primeiro a rebentar logo após o incêndio, acabou por regredir com a geada e só voltou a regenerar em maio. O pinheiro, como se regenera por semente, apenas nasceu em junho, mas em julho já tinha um desenvolvimento de $9 \mathrm{~cm}$ (Figura 18 e Fotografias 3 a 5).

Entretanto, à medida que o tempo foi decorrendo, diferentes espécies de herbáceas foram rebentando em cada uma das áreas amostra (Quadro I e Fotografias 6 a 8$)$.

Após este período de observação, a evolução da paisagem surge-nos como um movimento a que o tempo ajuda a dar sentido. A dinâmica própria de cada lugar assume particular sentido nestas paisagens mediterrâneas, onde os fatores locais a ter em conta para o processo de regeneração vegetativa são inúmeros. A influência de um único fator (precipitação, geada, temperatura elevada, etc.) pode ter efeitos diversos de lugar para lugar, dependendo muito de outras características físicas, nomeadamente do solo (composição, espessura...), bem como do conjunto das condições naturais, variáveis ao longo do tempo.

Por isso, as marcas deixadas pelos incêndios florestais podem permanecer mais ou menos tempo na paisagem, desde alguns meses a vários anos até desaparecerem totalmente, consoante se trate de herbáceas, arbustos ou árvores. Por outro lado, a ideia pré-concebida de que Portugal e, mais concretamente, a área de estudo estão a perder floresta, poderá ser uma ideia um tanto incorreta. Se foi verdade, ainda num passado recente, na atualidade verifica-se uma certa tendência para a estabilização da cobertura vegetal, com a maior parte do espaço com aptidão florestal ocupado por mato, mas, em resultado do absentismo de muitos proprietários florestais, observa-se até uma certa expansão das espécies arbóreas tradicionais (Quercus pyrenaica) 


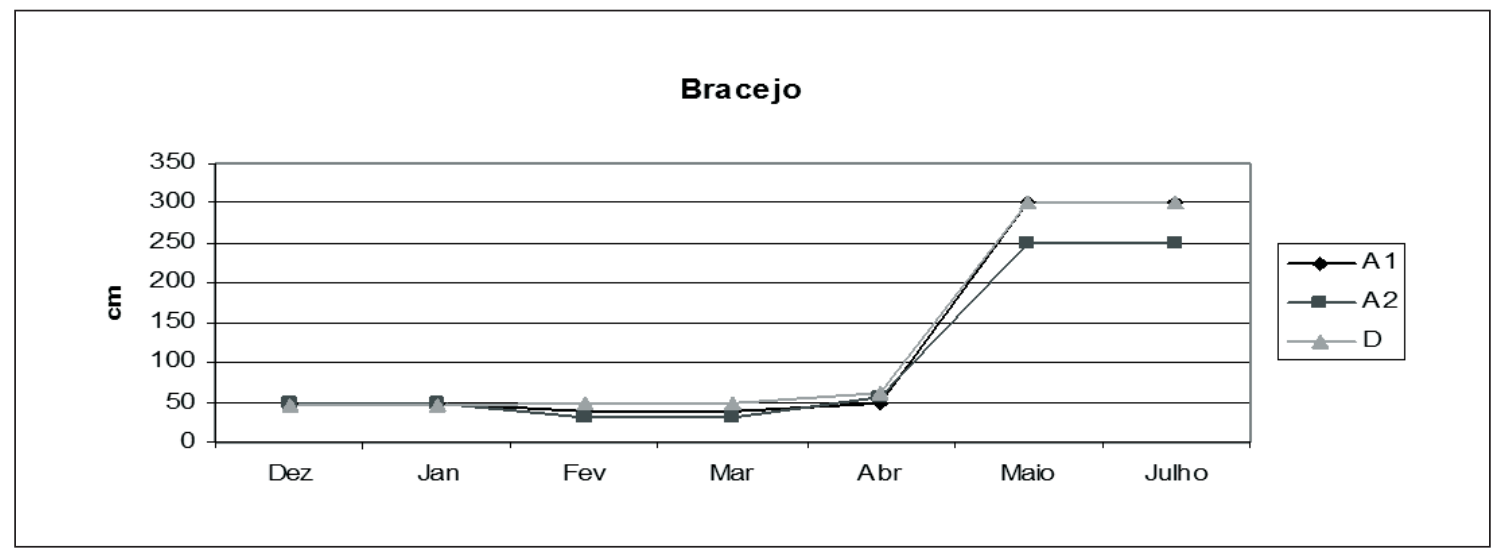

Figura 16

Evolução do crescimento do bracejo nas diversas áreas-amostra.

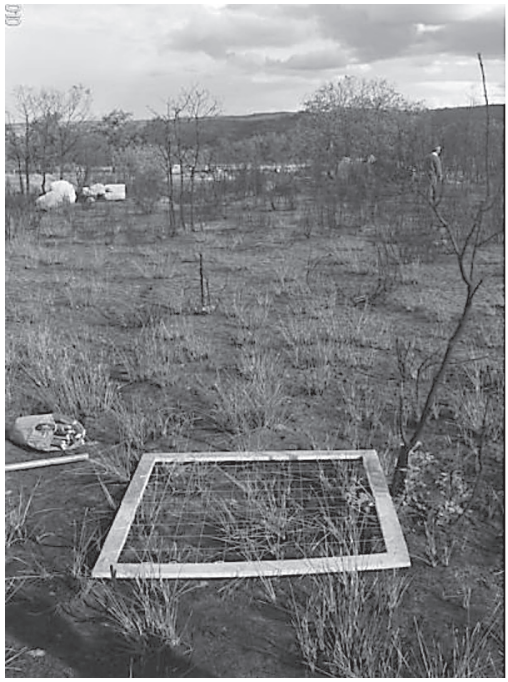

A

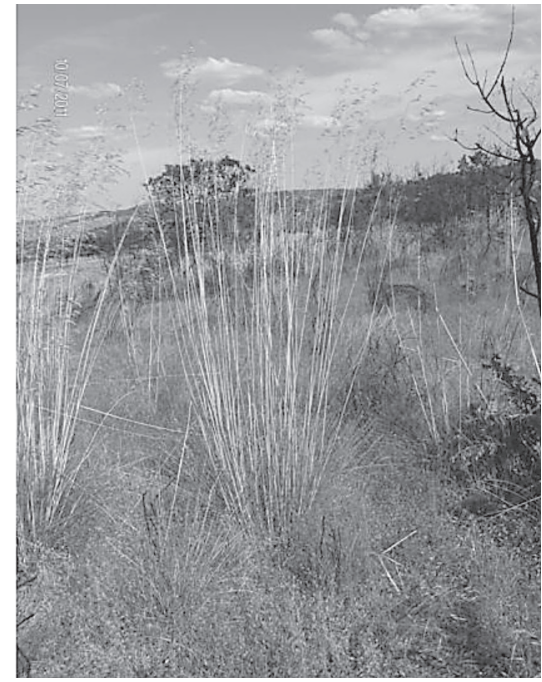

B

Fotografia 1

Evolução do bracejo na área-amostra A, entre outubro de 2010 (A) e julho de 2011 (B).

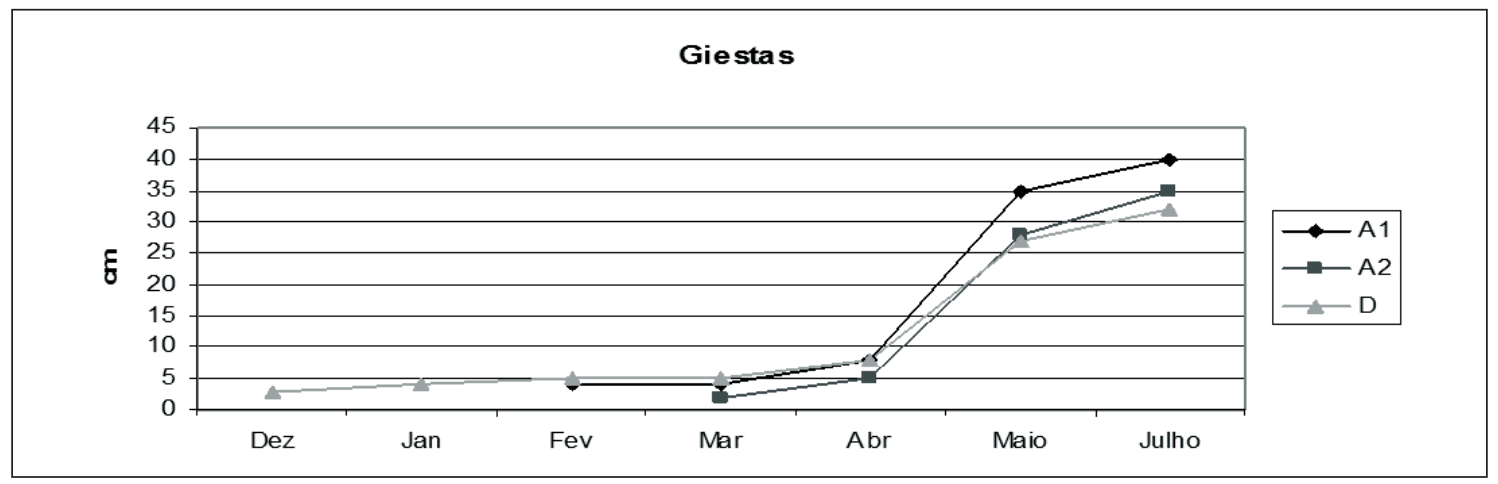

Figura 17

Evolução do crescimento das giestas nas diversas áreas-amostra. 


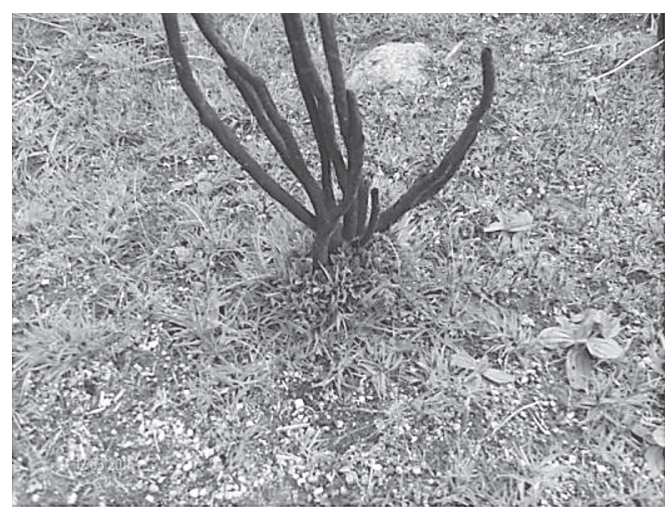

A

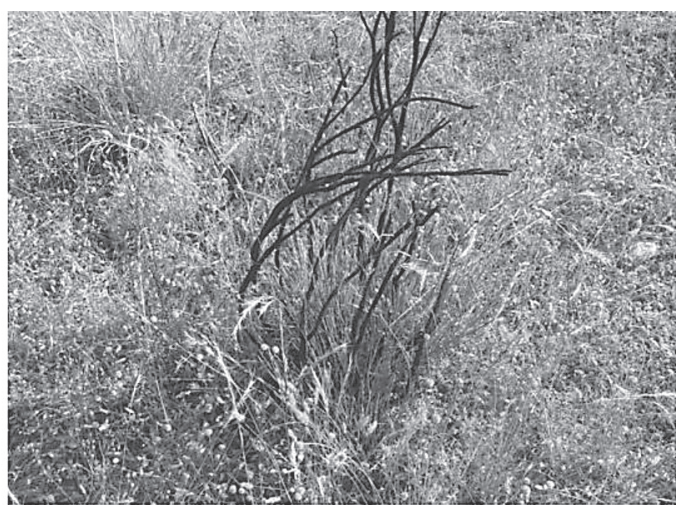

B

Fotografia 2

Evolução da giesta na área-amostra A, entre fevereiro (A) e em julho (B) de 2011.

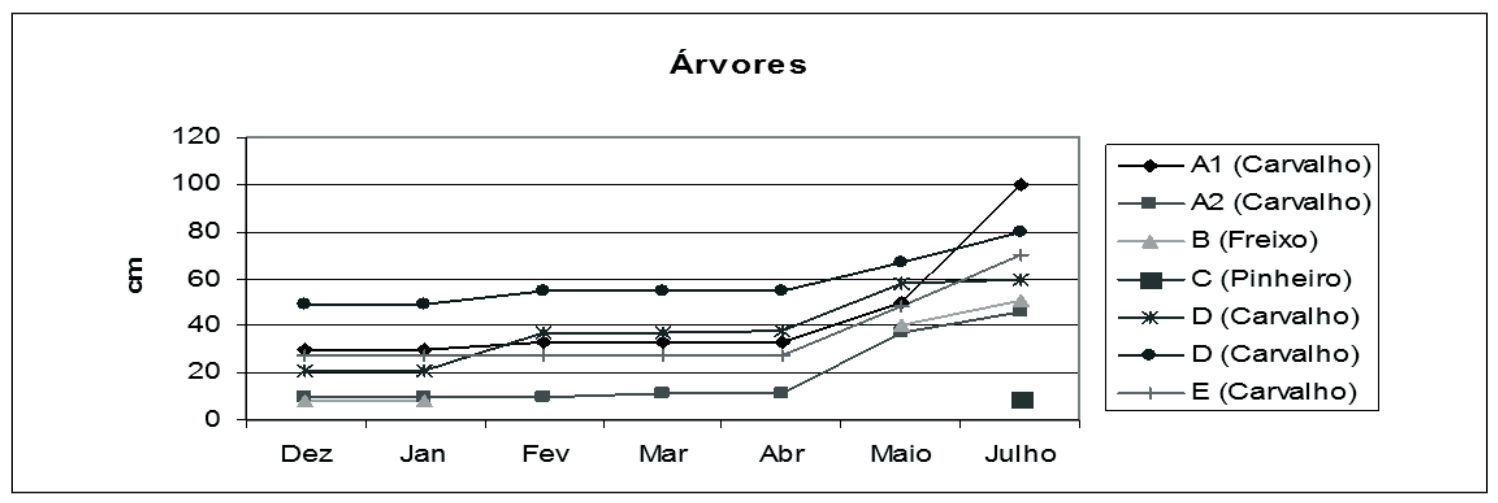

Figura 18

Evolução da rebentação das árvores nas diversas áreas-amostra.

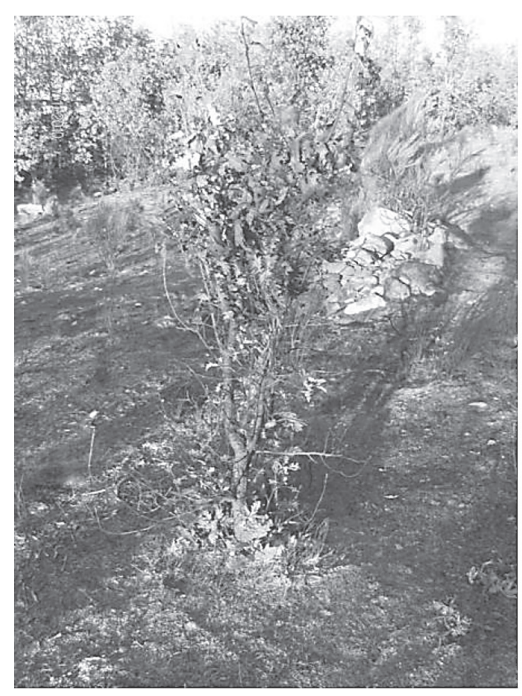

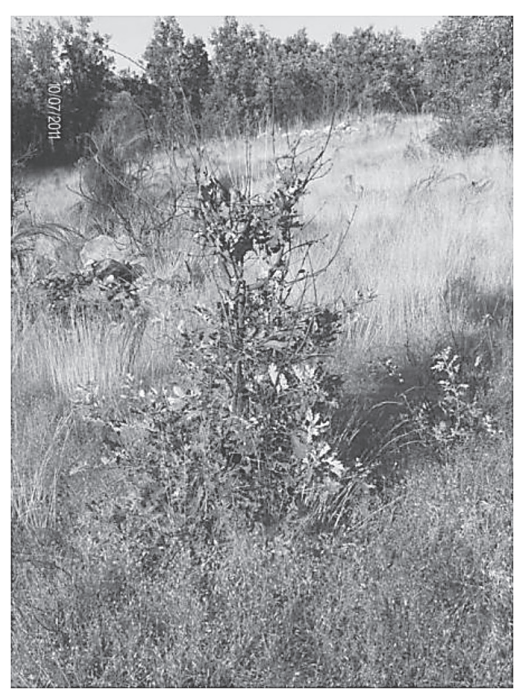

B

Fotografia 3

Evolução de um carvalho, na área-amostra D, entre dezembro de 2010 (A) e julho de 2011 (B). 
Quadro I

Início da regeneração das diferentes herbáceas, ao longo do tempo, nas áreas-amostra estudadas.

\begin{tabular}{|c|c|c|c|c|}
\hline \multirow[t]{2}{*}{ Espécie vegetal } & \multicolumn{4}{|c|}{ Dezembro } \\
\hline & $\mathrm{A}_{1}$ & $\mathrm{~A}_{2}$ & B & $\mathrm{E}$ \\
\hline Anthemis arvensis & & • & & \\
\hline Anthemis mista & $\bullet$ & & & \\
\hline Brassica barrelieri & - & • & • & - \\
\hline Campânula lusitanica & & $\bullet$ & & \\
\hline Capsella bursa-pastoris & $\bullet$ & $\bullet$ & & \\
\hline Cardamine hirsuta & $\bullet$ & & & \\
\hline Carduus sp. & & & & - \\
\hline Crepis vesicaria & & & & • \\
\hline Daphne gnidium & & $\bullet$ & & - \\
\hline Erodium cicutarium & & & $\bullet$ & \\
\hline Festuca sp. & $\bullet$ & $\bullet$ & & \\
\hline Galium aparine & & & $\bullet$ & \\
\hline Geranium rotundifolium & & & $\bullet$ & - \\
\hline Hymenocarpus lotoides & & $\bullet$ & & \\
\hline Hypochaeris radicata & $\bullet$ & & & \\
\hline Lamium amplexicaule & & $\bullet$ & $\bullet$ & \\
\hline Lamium purpureum & & & $\bullet$ & \\
\hline Lupinus gredensis & & & & - \\
\hline Malva sp. & & & & - \\
\hline Muscari cumoso & & $\bullet$ & & \\
\hline Ornithopus sp. & $\bullet$ & & $\bullet$ & - \\
\hline Plantago lanceolata & & & & - \\
\hline Poa annua & & $\bullet$ & $\bullet$ & \\
\hline Poa bulbosa & & & & - \\
\hline Pulicaria odora & & & $\bullet$ & \\
\hline Ranunclus sp. & & & $\bullet$ & \\
\hline Raphanus raphanistrum & - & - & $\bullet$ & • \\
\hline Rumex bucephalophorus & $\bullet$ & $\bullet$ & & - \\
\hline Sanguisorva sp. & - & - & & - \\
\hline Saxifraga granulata & & $\bullet$ & & \\
\hline Scolymus hispanicus & & & $\bullet$ & \\
\hline Senecio sylvaticus & & & $\bullet$ & - \\
\hline Senecio vulgaris & & & $\bullet$ & \\
\hline Spergula arvensis & $\bullet$ & & & \\
\hline Stellaria media & & & $\bullet$ & \\
\hline Teesdalia nudicaulis & & $\bullet$ & & \\
\hline Thapsia villosa & & & & - \\
\hline Torilis arvensis & & & & - \\
\hline Trifolium sp. & & & $\bullet$ & - \\
\hline Tuberaria lignosa & - & & & \\
\hline Umbilicus rupestris & & & & - \\
\hline Vulpia myurus & & - & & \\
\hline
\end{tabular}

\begin{tabular}{|l|c|c|c|c|c|c|c|c|c|}
\hline \multirow{2}{*}{ Espécie vegetal } & \multicolumn{2}{|c|}{ Março } & \multicolumn{1}{c|}{ Abril } & \multicolumn{5}{c|}{ Maio } \\
\hline & $\mathrm{A}_{2}$ & $\mathrm{~B}$ & $\mathrm{E}$ & $\mathrm{A}_{1}$ & $\mathrm{~A}_{2}$ & $\mathrm{~B}$ & $\mathrm{C}$ & $\mathrm{D}$ & $\mathrm{E}$ \\
\hline Lamium amplexicaule & $\bullet$ & $\bullet$ & & & & & & & \\
\hline Saxifraga granulata & $\cdot$ & & & & & & & & \\
\hline Senecio vulgaris & & $\bullet$ & & & & & & & \\
\hline Teesdalia nudicaulis & $\cdot$ & & & & & & & & \\
\hline Belardia trixago & & & $\bullet$ & & & & & & \\
\hline Brassica barrelieri & & & $\bullet$ & & & & & & \\
\hline Euphoria oxifila & & & $\bullet$ & & & & & & \\
\hline Lamium amplexicaule & & & $\bullet$ & & & & & & \\
\hline Raphanus raphanistrum & & & $\bullet$ & & & & & & \\
\hline Senecio vulgaris & & & $\bullet$ & & & & & & \\
\hline Teesdalia nudicaulis & & & $\bullet$ & & & & & & \\
\hline Brisa maxima & & & & & & & $\bullet$ & & \\
\hline Campânula lusitanica & & & & $\bullet$ & $\bullet$ & & & & \\
\hline Cytisus multiflorus & & & & & & & $\bullet$ & & \\
\hline Hymenocarpus lotoides & & & & $\bullet$ & $\bullet$ & & & $\bullet$ & $\bullet$ \\
\hline Linaria elegans & & & & & & & $\bullet$ & & \\
\hline Lupinus angustifolius & & & & & & & $\bullet$ & & \\
\hline Lupinus galensis & & & & & & & $\bullet$ & & \\
\hline Muscari cumoso & & & & $\bullet$ & $\bullet$ & & $\bullet$ & & \\
\hline Ornithopus sativus & & & & & & $\bullet$ & & & \\
\hline Ranunclus sp. & & & & & & & $\bullet$ & & \\
\hline Thapsia vilosa & & & & & & $\bullet$ & & \\
\hline Vulpia myurus & & & & & & & \\
\hline
\end{tabular}

que, assim, paulatinamente, parecem estar a recuperar, aliás um processo que poderá vir a ser muito mais rápido se, para tal, houver contribuição do ser humano.

\section{Considerações finais}

As mudanças que se foram fazendo sentir nas estruturas socioeconómicas, sobretudo, a partir de meados do século XX, alteraram os processos de uso e de ocupação do solo, pelo que a análise dos fatores naturais, socioeconómicos e político-estruturais neles intervenientes permitem conhecer as principais causas que levaram ao abandono e subutilização do espaço agrícola.

De facto, a conjugação de diversos fatores conduziu ao desmoronamento dos sistemas tradicionais de produção, por terem sido incapazes de se adaptar às novas regras estabelecidas pelos mercados. Por outro 


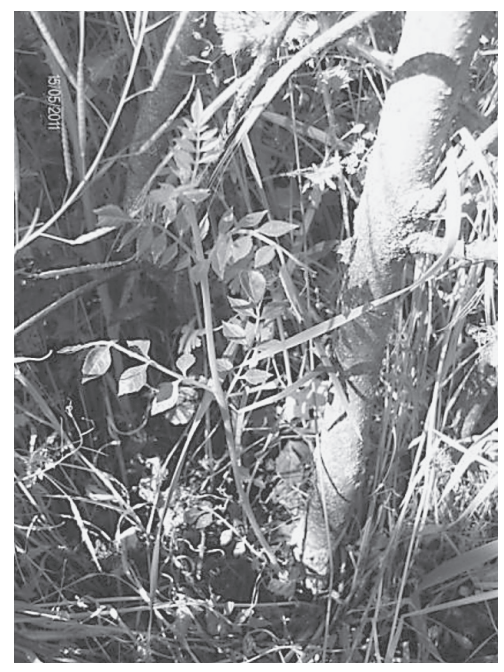

Fotografia 4

Rebento de freixo da área-amostra B, em maio de 2011.

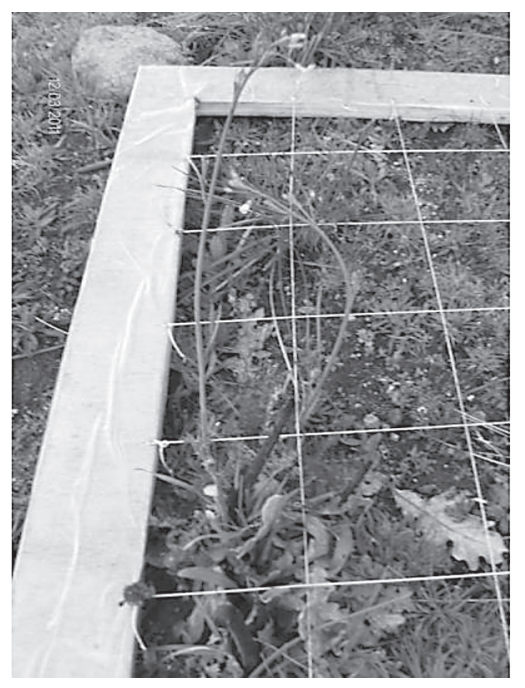

Fotografia 6

Herbáceas em flor, na área-amostra A: Brassica barrelieri e Lamium amplexicaule (A); Saxifraga granulata (B).

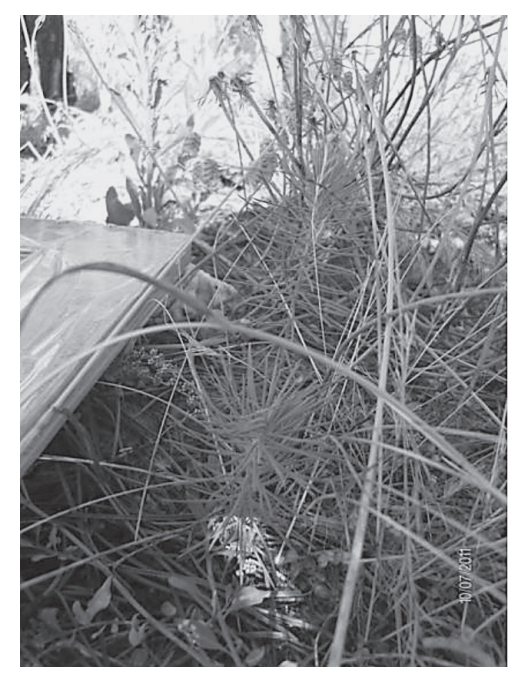

Fotografia 5

Pinheiros bravos recém-nascidos, na área-amostra C, em julho de 2011.

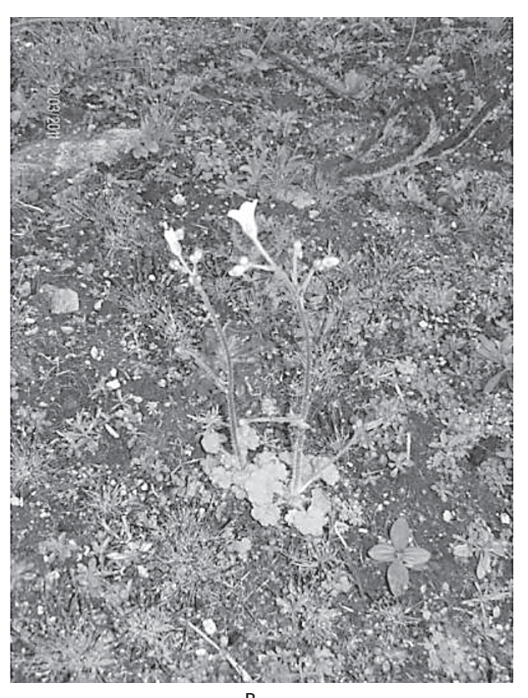

B

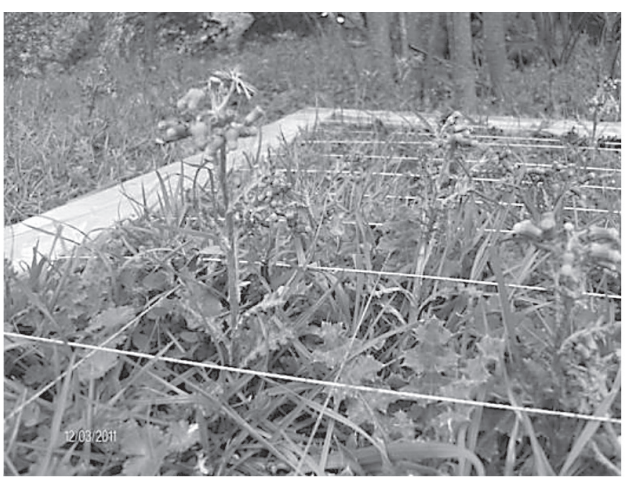

A

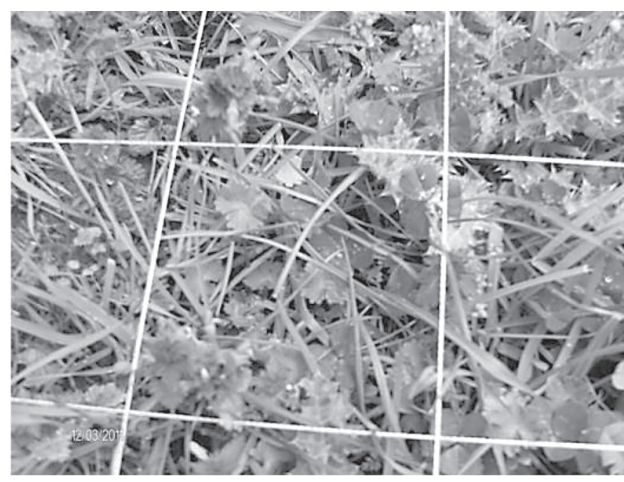

B

Fotografia 7

Pormenores da área-amostra B: Senecio vulgaris (A) e Lamium amplexicaule (B). 


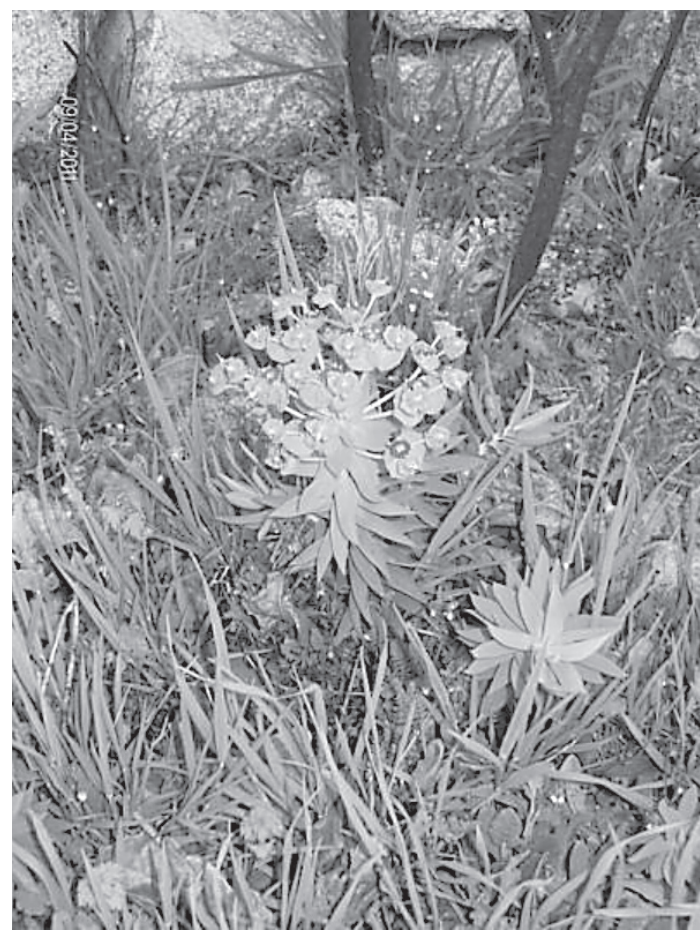

Fotografia 8

Pormenor da área-amostra E, com Euphoria oxifila em flor.

lado, o afastamento destas áreas dos centros de decisão e poder, também contribuiu para algumas das mudanças com mais expressão neste território e que, entre outras, se refletem na sua elevada suscetibilidade a incêndios florestais, a qual decorre, essencialmente, da falta de gestão do espaço florestal.

Com efeito, o elevado número de ocorrências de incêndios florestais que tem atingido o distrito da Guarda, designadamente os concelhos do Sabugal, Guarda, Gouveia e Seia, bem como, a grande extensão das manchas ardidas, que têm afetado, de forma mais premente, os concelhos do Sabugal e da Guarda, são a expressão que, no território, materializa tais transformações.

Contudo, em termos de reabilitação da paisagem, o nosso país ocupa uma posição privilegiada, devido à sua posição geográfica de transição entre o Mediterrâneo e o Atlântico, o que lhe confere uma elevada produtividade primária, ou seja, um forte crescimento das espécies vegetais e, muito em particular das arbustivas, vulgarmente designadas por mato, razão pela qual a recuperação da vegetação nas áreas ardidas é tão intensa e rápida.

Na realidade, não só é muito mais rápida do que nos países mais atlânticos, em que as temperaturas, designadamente no inverno, limitam o desenvolvimento ve- getativo, mas também do que nos países mais marcadamente mediterrâneos, onde a secura é mais acentuada e, por conseguinte, condiciona o crescimento da vegetação.

Assim, os estudos que se têm levado a cabo sobre a dinâmica da vegetação após incêndios (PESQUEIRA et al., 2005 e 2009; Reyes; Casal, 2008; Reyes e Trabaud, 2009; Reyes; Casal e Rego et al, 2009; Santos, 2010), têm demonstrado que, pouco tempo após a passagem destes, há uma recomposição e/ou um enriquecimento dos sistemas, desde que a frequência dos incêndios não seja muito elevada.

Deste modo, para a vegetação autóctone, os incêndios não têm sido um fator de degradação, mas antes uma ajuda à sua reabilitação, a qual tem vindo a evoluir favoravelmente, desde finais do século passado.

Uma desejável intervenção nas áreas de mato, para estimular esta recuperação, pode passar por uma gestão sustentável, que vai desde a afetação de alguns solos a outros usos, como a pastorícia, até ao aproveitamento do mato, tanto para produção de estrumes, contribuindo para o aumento da fertilização dos solos, como para a produção de energia, através de pequenas centrais de biomassa.

Com efeito, a pastorícia, que tem sido associada à degradação da qualidade ambiental do território, desde há pelo menos 150 anos, é provavelmente, em associação com o fogo controlado, a mais competitiva ferramenta de gestão destes territórios marginais e, nas nossas condições, um instrumento fundamental para a gestão racional dos incêndios, permitindo-nos retomar o papel de construtores de paisagem que deixámos quando abandonámos o mundo rural (SANTOS, 2010), mas tal só poderá acontecer quando o nosso país valorizar as atividades agro-silvo-pastoris, o que implica reconhecer que elas são uma das bases para a sobrevivência da humanidade e, em particular da nossa economia e da nossa sociedade.

\section{Bibliografia}

Carvalho, J. B. e Lopes, P. (2001) - Classificação de Incêndios Florestais. Manual do Utilizador. Direcção-Geral das Florestas, Lisboa, $34 \mathrm{p}$.

Contı, G. e FagarazzI, L. (2004) - "Sustainable mountain development and the key-issue of abandonment of marginal rural areas". The European Journal of Planning, $19 \mathrm{p}$.

Costa, J. C.; Aguiar, C.; Capelo, J.; Lousã, M. e Neto, C. (1998) "Biogeografia de Portugal Continental". Quercetea, pp. $1-57$. 
Cunha, L. e Gonçalves, A. B. (1994) - "Clima e tipos de tempo enquanto caraterísticas físicas condicionantes do risco de incêndio. Ensaio metodológico". Cadernos de Geografia, n 13, Coimbra, F. L. U. C., pp. 3-13.

Henriques, S. (2011) - Reincidência de incêndios florestais no distrito da Guarda. Fatores desencadeantes $e$ consequências ambientais da manifestação do risco dendrocaustológico. Dissertação de Mestrado em Geografia Física, Ambiente e Ordenamento do Território, apresentada à Faculdade de Letras da Universidade de Coimbra.

LouREnço, L. (1988) - "Tipos de tempo correspondentes aos grandes incêndios florestais ocorridos em 1986 no Centro de Portugal”. Finisterra, XXIII, Lisboa, pp. 251 $-270$.

LouRenço, L. (1992) - "Avaliação do risco de incêndio nas matas e florestas de Portugal continental". Finisterra, XXVII, 53-54, Lisboa, pp. 115-140.

LouRenço, L. (2004) - Manifestações do Risco Dendrocaustológico, Coletâneas Cindínicas IV. Núcleo de Investigação Científica de Incêndios Florestais, FLUC, Coimbra.

LouRenço, L. (2006) - Paisagens de socalcos e riscos naturais em Vales do Rio Alva, Coletâneas Cindínicas VI. Núcleo de Investigação Científica de Incêndios Florestais, FLUC, Coimbra.

LOURENço, L. (2007) - Riscos Ambientais e Formação de Professores (Atas da VI Jornadas Nacionais do Prosepe), Coletâneas Cindínicas VII. Núcleo de Investigação Científica de Incêndios Florestais, FLUC, Coimbra.

NunEs, Adélia (2000) - "O risco de incêndio florestal e a prática da pastorícia em 4 concelhos da Serra da Estrela: tentativa de correlação". Territorium, 7, Minerva Coimbra, pp. 55-64.

NunEs, Adélia (2002/04) - "Uso do solo em Portugal Continental: aspetos gerais da sua evolução". Cadernos de Geografia, n²1/23, FLUC, Coimbra, pp. 91-103.

NunEs, Adélia (2007) - Abandono do espaço agrícola na "Beira Transmontana": extensão, causas e efeitos ambientais. Dissertação de Doutoramento em Letras, área de
Geografia, especialidade em Geografia, apresentada à Faculdade de Letras da Universidade de Coimbra.

Pausas, J. G. (2004) - "La recurrencia de incendios en el monte mediterráneo". In: Vallejo, V. R. e Alloza, J. A. (eds.) - Avances en el estudio de la gestión del monte mediterráneo. Fundación Centro de Estudios Ambientales del Mediterráneo, Valencia.

Pesqueira, X. M.; Muñoz, A.; Álvarez, R.; García-Duro, J.; Reyes, O.; Basanta, M. e CASAL, M. (2005) - "Estudio ecológico del matorral atlántico de interés para conservación. Respuesta estructural a usos tradicionales en Galicia". Rev. Academia Galega de Ciencias, XXIV, pp. 41-60.

Pesqueira, X.M.; Muñoz, A.; Álvarez, R.; García-Duro, J.; ReYES, O. e CASAL, M. (2009) - "Spatial and temporal patterns in structure and diversity of Mediterranean forest of Quercus pyrenaica in relation to fire". Forest Ecology and Management, Vol. 257, Elsevier, pp. 1596-1602.

Rebelo, Fernando (1980) - "Condições de tempo favoráveis à ocorrência de incêndios florestais", Biblos, LVI, Coimbra, pp. 653-673.

REYES, O. e CASAL, M. (2008) - "Regeneration models and plant regenerative types related to the intensity of fire in Atlantic shrubland and woodland species". Journal of Vegetation Science, 19, Opulus Press, Uppsala, pp. 575-583.

Reyes, O. e Trabaud, L. (2009) - "Germination behaviour of 14 Mediterranean species in relation to fire: smoke and heat". Plant Ecol 202, Springer Science Business Media B. V., pp. 113-121.

Reyes, O.; CASAL, M. e Rego, F. C. (2009) - "Resprouting Ability of Six Atlantic Shrub Species". Folia Geobot, 44, Institute of Botany, Academy of Sciences of the Czech Republic, pp. 19-29.

Santos, H. P. (2010) - Do tempo e da paisagem. Manual para leitura de paisagens. Principia Editora, Cascais.

SILVA, J. S. (2007) - "Proteger a floresta - Incêndios, pragas e doenças". Árvores e florestas de Portugal, Vol. 8, Público, Comunicação Social S.A., Fundação LusoAmericana para o Desenvolvimento, Lisboa. 